\title{
COLlaborative DESIGN SYSTEMS TO IMPROVE Virtual DEVElopMENT OF MECHATRONIC PRODUCTS
}

\author{
Dragoi, G.; Rosu, S.M.; Rosu, L.; COTET, C.E. \& \\ DRAGOMIRESCU, C.G.
}

Abstract: This paper presents a solution of a next generation engineering working environments implemented in the experimental platform for training, research and consulting in the new digital economy (CESICED) and describes a core information technology which this systems can be built on. The platform is developed at University POLITEHNICA of Bucharest in the PREMINV center. We emphasize on special skills requirements for collaborative design of the mechatronics products. Within the framework of its activities on collaborative engineering, the PREMINV set up training projects aiming at developing competence's in this field with objectives of education training but also research, and industrial transfers.

Key words: collaborative design systems, mechatronics, virtual enterprise, virtual team, outsourcing
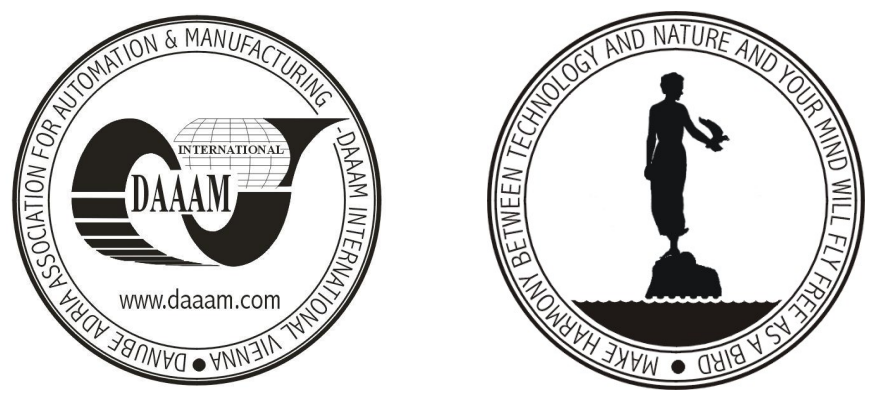

Authors' data: Dr. eng. Dragoi, G[eorge]*; Eng Rosu, S[ebastian] M[arius]*; Eng. Rosu, L[uminita $]^{* *}$; Dr. eng. Cotet, C[ostel] E[mil]*; Ass. Prof. Dr.Ing. Dragomirescu, C[ristian] G[eorge]*; * University POLITEHNICA of Bucharest, Splaiul Independentei 313, sector 6, Bucharest, Romania, ** Grup ROMET SA Buzau, GRUP ROMET SA, Sos. Brailei no.15, 5100, Buzau, Romania, gdragoi@mix.mmi.pub.ro, sebastianrosu@stsnet.ro, luminita@romet.ro, costel@mix.mmi.pub.ro, dragom@cat.mec.pub.ro

This Publication has to be referred as: Dragoi, G.; Rosu, S.M.; Rosu, L.; Cotet, C.E. \& Dragomirescu, C.G. (2007). Collaborative Design Systems to Improve Virtual Development of Mechatronic Products, Chapter 20 in DAAAM International Scientific Book 2007, B. Katalinic (Ed.), Published by DAAAM International, ISBN 3-901509-60-7, ISSN 1726-9687, Vienna, Austria

DOI: $10.2507 /$ daaam.scibook.2007.20 